\title{
Economic regulation of development methods for water injection at explored fields
}

\section{Zarnigor BOBOJONOVA ${ }^{1}$}

Tashkent State Technical University named I.A. Karimov

\section{ARTICLE INFO}

Article history:

Received October 2021

Received in revised form

15 October 2021

Accepted 20 November 2021

Available online

15 December 2021

\section{Keywords:}

industrial economics, geology and hydrogeology,

methods of field

development.

\begin{abstract}
This article describes the technological methods of developing water injection, if necessary, at the explored fields. Economic methods and approaches for optimizing the expenditure of the company's financial resources are also analyzed. In addition, the possibilities of water injection are given in relation to various economic situations, namely in the context of economic indicators.
\end{abstract}

2181-1415/C 2021 in Science LLC.

DOI: https://doi.org/10.47689/2181-1415-vol2-iss11/S-pp37-41

This is an open access article under the Attribution 4.0 International (CC BY 4.0) license (https://creativecommons.org/licenses/by/4.0/deed.ru)

\section{Dalalarda suv quyishni rivojlantirish usulini iqtisodiy tartibga solish}

\section{Kalit so'zlar:}

sanoat iqtisodiyoti,

geologiya va gidrogeologiya,

konlarni o'zlashtirish

usullari.

\section{ANNOTATSIYA}

Ushbu maqolada dalalarga suv quyish usullarini ishlab chiqish va ularning kompaniya byudjetini tartibga solishni optimallashtirish uchun iqtisodiy usullari tasvirlangan. Shuningdek, iqtisodiy ko'rsatkichlar bo'yicha turli usullarni kiritish misollari keltirilgan.

\section{Экономическое регулирование способов разработки по закачке воды на разведанных месторождениях}

\begin{tabular}{l}
\hline Ключевые слова: \\
экономика \\
промышленности, \\
геология м гидрогеология, \\
методы разработки \\
месторождений.
\end{tabular}

\begin{abstract}
АННОТАЦИЯ
В данной статье описаны технологические методы разработки закачки воды в случае необходимости на разведанных месторождениях. Также анализируются экономические методы и подходы для оптимизации расхода финансовых средств компании. Кроме того, приведены возможности закачки воды применительно к различным экономическим ситуациям, а именно в разрезе экономических показателей.
\end{abstract}

\footnotetext{
${ }^{1}$ Doctoral Tashkent State Technical University named I.A. Karimov. Tashkent, Uzbekistan.
} 
In 2020, field development actively responded to the serious problems caused by low oil prices, firmly established the concept of "outstanding development quality and benefits", insisted on focusing on benefits, actively pursued marketing strategies to evaluate development projects, promoted its planned trumps and innovative projects, also promoted operational efficiency and profitable oil production. To make it efficient and effective again, it is necessary to adhere to profitable scientific developments and make every effort to promote this development strategy in accordance with laws and regulations.

The economy of the oil and gas sector is closely connected with the technological processes of the oil and gas business, Each technological element affects the estimate of deposits. The development of oil and gas wells requires a synergetic, comprehensive plan and this requires analysis of the development of an oil field and identification of discrepancies in design and actual production indicators. The system of oil field development depends on technological methods of development regulation. The most common method is considered to be changing the operating mode of production by injection wells. This leads to a decrease or, conversely, an increase in the flow rate of the injected reservoir. In the Bukhara stage, this method is the injection of pressure in the reservoir from another well. The development of water injection in an oil field refers to the completion of investments in the construction of production facilities in the field, and after the creation of production facilities, at an early stage of operation or during the production process, the water injection well is used to replenish energy consumption. In order to increase crude oil production and prolong the operation time of the oil reservoir field, improving the extraction of raw materials is considered optimal in order to regulate this method of oil field development.

In the case of development with water injection, with an increase in production time, the costs of pumping materials for displacement from the oil field and other costs of injection will change accordingly. At the same time, the extraction of raw materials will increase, and the water content in crude oil will continue to grow, which will inevitably lead to corresponding changes. In the traditional economic assessment of oil fields, changes in operating costs and an increase in water availability are usually not taken into account, and this at one time has a bad effect on production.

Based on the facts of water injection in oil fields, combined with a change in the law of operating costs for the development of water injection and an increase in reservoir waterlogging, this article establishes a model for the economic evaluation of the development of water injection in the field. This model determines the initial economic production and the internal rate of return of an individual well and reservoir of the quantitative relationship between the depth of occurrence and water availability.

Based on the data obtained, it is possible to resort to SPSS software to perform regression analysis and to obtain a regression model between the internal rate of return and crude oil production, reservoir depth and waterlogging. It is necessary to use a regression analysis model in order to easily obtain the results of an economic assessment of the development of water injection at the field.

The creation and application of the model of economic assessment of the development of flooding of oil fields is not only a supplement and improvement of the traditional economic assessment, but also an attempt to apply methods of economic assessment of the development of flooding of oil fields. It can provide a way of thinking and research for the economic assessment of the development of flooding of oil fields. 
The creation of an economic evaluation model for the development of water injection at an oil field is based on the use of basic principles of technical economy and methods of dynamic break-even analysis to discount both income and profitable costs from the development of water injection at the field to obtain net present value income from the development of water injection at the field, namely, the net present value of income is equal to the net present value of investments in the construction of production facilities during the development of water injection at the field.

Characteristics of the economic assessment model for the development of water injection at the field:

- the income assessment takes into account the method of reducing production at the field and the cumulative tax rate;

- the assessment of profitable expenses takes into account the initial water cut, the limit of water cut and the method of increasing water cut, and also takes into account that with the change in water cut, the operating costs of each year during the evaluation period will change accordingly;

- assessment of the construction of production facilities. Investments take into account the share of water injection wells, drilling investments, ground construction and other investments.

According to the characteristics of the construction and development of production capacities of an oil field, they are divided into the upper stage of production, the stage of stable production and the stage of decline (late stage). For relatively small blocks using continuous development or an oil field, it is usually possible to combine the production stage with the stable production stage. Thus, based on this reasoning, the income from the development of water injection at the field is also divided into income from the stable stage of production and income from the declining stage, that is, the remainder of the proceeds from the sale of crude oil after deduction of sales tax and sales tax and additional fees mainly include value added tax, income tax, resource tax and other taxes.

Sales tax and additional fees are considered at the general tax rate:

(1);

The present value of income during the reduction period is:

$$
\begin{aligned}
\mathrm{C}_{д}=\sum_{t=\Pi 1+1}^{n 2} Q & \left(1-D^{T)^{-\Pi 2}}(\text { Кп }(1-\mathrm{Tx}))(1+Я \mathrm{p})(1+x)^{-\mathrm{T}}\right) \mathrm{C}_{д} \\
& =\sum_{t=\Pi 1+1}^{n 2} Q\left(1-D^{T)^{-\Pi 2}}(\text { КП}(1-\mathrm{Tx}))(1+Я \mathrm{p})(1+x)^{-\mathrm{T}}\right)
\end{aligned}
$$

$\mathrm{C}_{\mathrm{H}}=\mathrm{C}_{\mathrm{H}}=$-present value of income for a stable production period, soums;

$\mathrm{C}_{\mathrm{A}}$ - the present value of income in the period of decreasing, soums;

$\mathrm{Q}$ - Annual oil production, $\mathrm{t}$;

КП - crude oil commodity rate, \%;

$\mathrm{P}$ - is the selling price of crude oil, soums / $t$;

I - internal profitability, \%;

$T_{\mathrm{x}}$ - complex tax rate, \%;

D - Annual cumulative rate of decline, \%;

$n_{1}$ is the period of stable production, a;

$n_{2}$ - period of decline, a. 
After the field's production facilities are put out of operation, the field goes into the development stage, and the corresponding costs and expenses will be incurred. Profitable expenses are the corresponding expenses incurred to generate income from crude oil. Profitable expenses usually include annual operating expenses, management expenses, finance expenses, sales expenses, etc. Profitable costs also include a stable production stage and a decreasing stage. In accordance with the actual situation in the oil field, the profitable costs measured for one well mainly include material costs, fuel costs, operating costs in the well, logging and testing costs of wells, maintenance and repair costs, etc. Costs, costs for the extraction of light hydrocarbons, costs for the management of plants and mines, recurring costs, etc. In addition, there are electricity costs, oil and gas refining costs, and oil displacement injection costs, which are measured in tons of liquid. By combining a decrease in crude oil production and an increase in water availability during the development of water injection at the fields, operating costs are obtained for each year during the evaluation period.

Capital expenditures for the development of water injection in oil fields mainly include investments in drilling projects, investments in ground construction and auxiliary projects, as well as other investments. In drilling investments, they mainly include investments in oil wells and water injection wells. At the same time, according to the different characteristics of the reservoir and the geological structure, the proportion of water injection wells and the total cost of drilling per unit area should be taken into account. Complex drilling costs include the costs of complex projects such as drilling, logging, logging and testing of oil.

$$
\begin{aligned}
Z=\sum_{t=1}^{n_{0}}\left(\left(C \times H+D_{m}+Q_{t}\right)\left(1+Я_{\mathrm{p}}\right)^{\left(n_{0}+1\right)-T}\right) Z \\
=\sum_{t=1}^{n_{0}}\left(\left(C \times H+D_{m}+Q_{t}\right)\left(1+Я_{\mathrm{p}}\right)^{\left(n_{0}+1\right)-T}\right)
\end{aligned}
$$

$\mathrm{Z}$ - capital expenditures in soums;

C - The total cost of drilling, sum / m;

$\mathrm{H}$ - the depth of the well, m;

$D_{\mathrm{M}}$ - investments in land construction;

$Q_{\mathrm{T}}$ - other investments;

$n_{0}$ - The construction period of production facilities.

The choice of crude oil level can be obtained by statistical analysis with reference to the statistics of oil fields in recent years, or it can be selected based on experience. In this study, $90 \%$ is selected; the price of crude oil can refer to the price of crude oil on the international market or the price of crude oil in the economic evaluation of domestic oil fields. The method of selecting the full tax rate can be obtained by statistical analyses based on oil sales tax statistics, as well as statistics of additional revenue and sales revenue in recent years.

In the economic assessment of the development of flooding, in addition to taking into account the parameters of the general economic assessment of the development of the field, it is also necessary to take into account the method of increasing the water content, 
combining the initial water content and the maximum water content to obtain the appropriate water content. In this case, there is a rate of increase, and then a corresponding correlation, which also has an economic relationship between other variables. In a general economic assessment, operating costs are usually measured according to the unit's performance. In the economic assessment of the development of water injection, the parameters of operating costs are divided into a measurement for a separate well, a measurement for liquid extraction and a measurement for a unit of production. These are three measurement methods, which are also established taking into account the characteristics of the development of water injection.

At the initial humidity 5\%, 10\%, 15\%, 20\%, 25\%, 30\%, 35\%, 40\%, 45\%, 50\%, 55\%, $60 \%, 65 \%, 70 \%, 75 \%, 80 \%, 85 \%, 90 \%$ (the maximum water content of $96 \%$ ), it is possible to calculate the corresponding full rate of increase in water content; then calculate the relationship between the internal rate of return and the depth of the well, daily production of one well and complex water content, profitability and depth of the well, daily production of one well and water content.

Based on the analysis of the characteristics of the development of water injection at an oil field and the principle of dynamic break-even analysis, a model of economic evaluation of the development of water injection at the field has been developed in this article. Under certain environmental conditions, a quantitative relationship is obtained between the daily production of an individual well and the internal return rate, well depth and water content, and the corresponding test data obtained are used to perform regression analysis using SPSS software to obtain the internal rate of return and the daily rate of an individual well. A regression analysis model between production, well depth and water availability, and then using the established regression analysis model, you can easily perform an economic assessment of the development of water injection in an oil field.

\section{REFERENCES:}

1. The center "Tarakkiet strategiyasi". "Tarakkiet 2018". Tashkent. - 2018.

2. Zakirov A.A., Ivonina I.E., Soatov E.A., Otto O.E. "Analysis of the activities of oil and gas industry enterprises in market conditions" - T.: "Fan va texnologiya", 2017.

3. Zakirov A.A., Zakirov A.A., Otto E., Khamroeva I.N., Karimov M.K. "Management of oil and gas resources of the Republic of Uzbekistan", Vol.: "Fan va texnologiya", 2019.

4. www.lex.uz.

5. www.stat.uz. 